For citation please use CYELP, volume 1. More information available at www.cyelp.com

\title{
GENDER EQUALITY AND THE PROCESS OF HARMONISATION OF THE CROATIAN LABOUR LAW*
}

\author{
Mario Vinković*
}

Summary: In the process of harmonisation of the Croatian legal system to the standards and principles of the acquis communautaire, the field of equal opportunities or gender equality has attracted a great deal of attention. Achieving de facto gender equality at all levels of social and political life, as well as acting de iure in the direction of refining and creating new solutions within the existing legislation, represents a high challenge for legal experts. The harmonisation process raises a dilemma as to whether the modifications which have been made are sufficient and of a good nomotechnical quality, and whether the whole process in this area can be regarded completed at this stage.

I.

Following the processes of convergence towards European integrations in general and particularly by signing the Stabilisation and Association Agreement ${ }^{1}$ in October 2001, and based upon Article 69 of the Pact, the Republic of Croatia has undertaken the responsibility to gradually harmonise its legislation in accordance with the acquis communautaire. In such a context, the issue of equal opportunities or gender equality has attracted a great deal of attention, although it has not been ratified by national parliaments of EU members and consequently it has not come into force. The principle of gender equality, as one of the general principles of the European Union, was promoted by the latest constitutional changes of 2001 in the Republic of Croatia into one of the highest values of our constitutional order, making the basis for the interpretation of the Constitution $^{2}$ itself. According to the latter statement, two basic questions arise: 1) has a significant step forward been taken relative to the process of harmonisation with primary legislation, as well as with nine relevant directives of the EU by the changes and amendments of the Labour Act passed in July 2003, i.e. could it be considered that the initial and foreseen process of harmonisation in this domain has been completed;2) could it be expected that, based

- An earlier version of this article was presented at the international conference From Legislation to Action: The Equality of Men and Women (European Experiences and Croatian Perspectives), organised within the framework of the Project on gender equality and the adjustment of constitutions and institutions (funded by the British Academy South Eastern Programme), on 4 December 2003 at the Faculty of Law, University of Zagreb, Republic of Croatia. I am grateful to all participants of this event for their lively discussion, ideas and conclusions, in particularly to Prof. Jo Shaw, Prof. Dr. Siniša Rodin, Fiona Beveridge, Dr. Jill Lovecy and Dr. Biljana Kašić

.* Mario Vinkovic, Ph.D. candidate, Faculty of Law, University of J. J. Strossmayer in Osijek.

${ }^{1}$ See the Proposal for a Council Decision concerning the signature of the Stabilisation and Association Agreement between the European Communities and its Member States and the Republic of Croatia on behalf of the European Community and the Proposal for a Council and Commission Decision concerning the conclusion of the Stabilisation and Association Agreement between the European Communities and their Member States, of the one part, and the Republic of Croatia, on the other part, http://europa.eu.int/comm/external relations/see/croatia/com01 371en.pdf.

${ }^{2}$ Article 3 of the Constitution 'Freedom, equal rights, national equality and equality of genders, love of peace, social justice, respect of human rights, inviolability of ownership, conservation of nature and the environment, the rule of law and democratic multiparty system are the highest values of the constitutional order of the Republic of Croatia and the ground for the interpretation of the Constitution." For English version of the Croatian Constitution see http://www.osce.org/odihr/elections/field_activities/2003croatia/doc/hr_const.pdf . 
on the existing legislative solutions, a major breakthrough has been made with respect to offering substantial protection from gender discrimination in the area of labour relations/rights.

\section{II.}

Extending the content of Article 2 of the Labour Act, ${ }^{3}$ which forbids discrimination, the Government of the Republic of Croatia has forwarded into the parliament procedure amendments and modified proposals of the existing legislative solutions. However, in addition to recently introduced terms like direct and indirect discrimination, which mutatis mutandis correspond to the definitions of the provisions of the Council Directive $2000 / 78 / \mathrm{EC}^{4}$ on establishing a general framework for equal treatment in employment and occupation, and Directive 2002/73/EC ${ }^{5}$ on amending Council Directive 76/207/EEC on the principle of equal treatment, as well as a great number of legal bases forbidding any type of discrimination, including discrimination based on sexual orientation, significant errors and omissions have undoubtedly been made. In our opinion, they represent a step backwards in the process of harmonisation and not an affirmation of the principle of gender equality based upon not only legal norms but also on determined and necessary attempts to eliminate widely dispersed social stereotypes concerning the traditional roles of women and men, especially in the immanent societies of the transitional provinces of South-Eastern Europe. We are primarily thinking here about the abolishment of the provision on the positive discrimination of the underrepresented sex in cases where candidates of different sex are equally qualified, from the previous Article 3(2) of the Labour Act, with the explanation provided by the Government that the stated Article has not yielded the expected results. Hereby, one should bear in mind that the related provision of the Labour Act existed from 2001 to 2003, and due to such a short period, it could not have resulted in the expected effects. This is additionally supported by the fact that there exists a complete absence of national court practice in this domain. The problem of the underrepresented sex should have been treated much more carefully by attempting to disable potentially new discrimination conducts stemming from a relatively generalised definition of positive discrimination and not by eliminating the whole principle established, inter alia, on the basis of Article 141, paragraph 4, of the EC Treaty. The other reason contra elimination of the principle of positive discrimination in favorem of the underrepresented sex, which expresis verbis existed in the Labour Act, lies in the fact that its derogation caused the elimination of a normative basis for the battle against gender segregation in access to occupation and employment, including promotion. ${ }^{6}$ This has allowed national courts to make controversial decisions, such as those by ECJ in the case of Kalanke, ${ }^{7}$ the midwife case, ${ }^{8}$ or in the case of Marschall. ${ }^{9}$ The mentioned ECJ decisions are definitely unacceptable from the

\footnotetext{
${ }^{3}$ Zakon o radu, Narodne novine, No. 38/95, 54/95, 65/95, 17/2001, 82/2001 and 114/2003.

${ }^{4}$ Council Directive 2000/78/EC of 27 November 2000 establishing a general framework for equal treatment in employment and occupation [2000] Official Journal L 303, 02/12/2000.

${ }^{5}$ Directive 2002/73/EC of the European Parliament and of the Council of 23 September 2002 amending Council Directive 76/207/EEC on the implementation of the principle of equal treatment for men and women as regards access to employment, vocational training and promotion, and working conditions [2002] Official Journal L 269, $05 / 10 / 2002$.

${ }^{6}$. Cf. V Herman, M. Vinković, Ravnopravnost spolova - ogledi o izabranim pitanjima europskog i hrvatskog radnoga prava (2003) 3-4 Zbornik Pravnog fakulteta u Zagrebu, p. 837.

${ }^{7}$ Case C-450/93, Kalanke v Freie Hansestadt Bremen, [1995] European Court Reports I-3051.

${ }^{8}$ Case C-165/82, Commission v UK, [1983] European Court Reports 3431, [1984] 1 CMLR 44.

${ }^{9}$ Case C-409/95 Marshall, Helmut v Land Nordrhein-Westfalen, [1997] European Court Reports 6363. About the case cf. R. Blanpain, European Labour Law (2000) Kluwer Law International, p. 306.
} 
aspect of the current European gender mainstreaming concept, as well as contrary to the programmes of other bodies of the Union in this domain, but they do represent a clear indicator of ECJ political-dimension reflections. Since today the decisions in those cases would have been contextually significantly different, a dilemma remains about why the Government, while proposing amendments, continued to keep such an imprudent attitude towards eliminating the principle of positive discrimination. Moreover, in our opinion, sex segregation with respect to the choice of and access to employment and occupation, and in this connection the mentioned ECJ decisions, represent a form of indirect discrimination, since they enable the practice of putting one sex in an unfavourable position, often without any legitimate and justified aim. ${ }^{10}$

III.

Harassment and sexual harassment represent a novelty in the amendments to the existing Labour Act, since they have been introduced for the first time as separate institutes within the Croatian Labour Law and are denoted as forms of discrimination. The fundamental difference between them is that sexual harassment represents verbal, nonverbal or physical conduct of a sexual nature with the purpose of violating the dignity of a person trying to find a job or of an employee, and causes either fear or a hostile, humiliating or offensive environment. ${ }^{11}$ On the other hand, harassment in general is characterised by the lack of a sexual dimension, but exists through some other form of discriminatory behaviour. ${ }^{12}$ In the nomotechnical sense, we consider it an advantage that the burden of proof that there was no discrimination lies on the employer's side, ${ }^{13}$ which enables any victim, after having suffered a certain flagrant or a more indirect form of harassment and discrimination, not to be forced to pass through the procedure of providing evidence in a situation that would put her/him in an unfavourable position regarding the balance of power. Moreover, in the sense of protecting the employee's dignity in general, harassment and sexual harassment represent an infringement of duties regarding employment relations, whereby any employer employing more than 20 employees is obliged to appoint a person responsible for receiving and dealing with complaints about the protection of employees' dignity. ${ }^{14}$ However, it remains unclear, and probably left to collective agreements, codes of conduct and other autonomous acts, which actions can be taken by the employer in order to prevent harassment and sexual harassment if it is proven to exist. If the actions taken by the employer for the purpose of preventing harassment and sexual harassment are obviously inappropriate or behind the deadlines set by the law, the injured party (employee) has the right to stop working until she/he is provided with protection, under the condition that she/he also makes a demand for protection in a court of law. ${ }^{15}$ From the aspect of protection against sexual harassment, we believe that the practice of both national courts and employers will show whether a part of the foreseen norms of a dispositive nature would be sufficient to provide adequate protection or whether it would be necessary in this field to introduce norms ius cogens. All data acquired in the procedure of the protection of dignity against sexual harassment and harassment are classified, ${ }^{16}$ whereby the

\footnotetext{
${ }^{10}$ See D. Schiek, Sex Equality Law After Kalanke and Marshall (June 1998) 4 ELJ, No. 2., p. 148-166.

${ }^{11}$ Article 2b(3) of the Labour Act.

${ }^{12}$ Article 2b(2).

${ }^{13}$ Article 2d.

${ }^{14}$ Article 22a(5).

${ }^{15}$ Article 22a(6) and (7).

${ }^{16}$ Article 22a(10).
} 
employee's resistance to any type of behaviour representing harassment or sexual harassment should not be the reason for her/his discrimination. ${ }^{17}$

\section{IV.}

On the other hand, in our opinion, bans on female employees working night shifts in various industries that are present in our Labour Law represent a form of indirect discrimination and should be predominantly regulated by norms of a dispositive nature accompanied at the same time by strict legislative mechanisms, which would disable possible abuses of employers in this domain. We follow the same line of thought regarding Chapter IX of the Labour Act, which is dedicated to maternity protection. Although the Labour Act forbids unequal treatment of pregnant women, in the view of experts, a nomotechnical solution, which dedicates a special part/chapter to maternity issues, also represents a certain form of indirect discrimination, especially if we consider the content of some provisions. However, even the European Court of Justice (ECJ) recognised legitimacy in the conditions of the equal treatment principle in cases of protection relating to biological conditions prior to and after delivery. ${ }^{18}$ Moreover, it stated that any unequal treatment of women related to pregnancy or maternity constitutes direct sexual discrimination. ${ }^{19}$ In that context we also share the attitude that in this particular case the positive actions/measures are legitimate and proportional, but at the same time we must note that certain issues should necessarily be regulated by norms of a dispositive nature. In accordance with Article 56(1), an employer is forbidden to refuse to hire a woman due to her pregnancy, to fire her or to transfer her to any other job unless she personally insists on that, or unless it is required by her health condition, which should be certified by an authorised doctor. ${ }^{20}$ In the event of a dispute between an employer and a female employee, it is the authorised doctor who assesses whether a transfer to any other job is possible or not. ${ }^{21}$ The provision according to which the temporary transfer of a female employee must not involve a reduction in pay as a consequence is considered as a positive step that could disable possible indirect discriminatory practice in the domain of payment. The solution of the Croatian Labour Act complies with the Directive on the protection of pregnant women at work, ${ }^{22}$ which stipulates that if the employer cannot transfer a pregnant woman or a breastfeeding woman to any other suitable job, she is entitled to take leave and to corresponding pay compensation according to special rules. The only danger with respect to such a solution and special rules is our fear that they could establish a practice which could, considering their farreaching effects, result in indirect discriminatory practice, especially through the social security system, which even in the EU legal system suffers from certain forms of gender discrimination, i.e. gender inequality, due to the dominant coordination of legal rules in that field.

\footnotetext{
${ }^{17}$ Article 22a(11).

${ }^{18}$ Case C-184/83 Hofmann v Barmer Erstzkasse[1984] European Court Reports 3047, [1986] 1 CMLR 242. About the Case see and Peter Craig, Gráinne de Búrca, EU Law: text, Cases and materials (2000) Oxford University Press, 2 edition, p. 853-854.

${ }^{19}$ Cf. ibid. , p. 858.

${ }^{20}$ Article 57 (1).

${ }^{21}$ Article 57 (3).

${ }^{22}$ Council Directive 92/85/EC of 19 October 1992 on the introduction of measures to encourage improvements in the safety and health at work of pregnant workers and workers who have recently given birth or are breastfeeding (tenth individual directive within the meaning of article 16(1) of Directive 89/391/EC) [1992] Official Journal L 348/1, 28/11/1992.
} 
V.

With respect to equal pay for equal work and work of equal value, the latest amendments of the Croatian Labour Law in the process of harmonisation represent a breakthrough, which has already been made in the acquis. Namely, modifications of the Labour Act from 2001 refer to the provision on equal pay for equal work and work of equal value done by male and female employees, that was copied from Article 141(1) of the EC Treaty, whereby it was not precisely defined what is implied by equal pay for equal work and work of equal value. However, even today these definitions in the Labour Act are not literally copied. Definitions exist according to which equal pay for equal work and work of equal value is done by persons of different gender: 1) if they carry out the same job under the same or similar conditions or if they could replace each other with respect to the job they do, 2) when the job done by one of them is of a similar nature to the other one's, and the differences between the job done and conditions under which each of them works do not significantly influence the nature of the job in general or if they occur so rarely that they do not influence the nature of the job as a whole, 3) the job done by one of them is of equal value in comparison to the job done by the other one if the following is taken into account: qualifications, skills, manual work or not, responsibilities and conditions under which the job is done. ${ }^{23}$ Although such a definition in the Labour Act omits the definition of equal pay for equal work and work of equal value referred to in Article 141(2) of the EC Treaty, we believe that for the definition stated as above, even the EC Treaty provision would not be excessive, especially if the work in question refers to industry and industrial production. The Croatian definition regarding equal pay for equal work may actually include cases such as those in which the educational background of employees is not identical, but they do the same or similar work, whereas in that aspect the ECJ was more restrained.

Although the history of Article 141 of the EC Treaty is well known, it is also worth noticing that many EU countries are burdened by the problem of unequal pay for equal work at the practical level. In the Republic of Croatia the corresponding problem is less observable, although it does not mean that it is not present. The reason for this is not only the concept of two bread-winners in the family, which was inherited from the communist era, but also the total lack of atypical forms of employment contracts immanent to some member countries of the EU, on the basis of which women are predominantly hired, the consequence of which is often de facto inequality of pay for women and men. That problem is manifested in Croatia more post festum, within the social security system and after retirement, since then it becomes obvious that, despite allegedly equal pay for equal work, women and men very often do not draw equal amounts in their retirement allowance. However, that issue requires a detailed analysis and the reform of the national old-age pension insurance in which gender equality is to be placed on the agenda.

\section{Conclusion}

This short overview of national solutions regarding labour law in the field of gender equality and equal treatment raises a dilemma about whether modifications made in the harmonisation process are sufficient and of good quality, and whether the harmonisation process can be regarded as completed at this stage. The answer to this question is more complex than it seems at first sight. The Republic of Croatia entered the harmonisation process with a procedure which is clearly open to heavy criticism. Namely, prior to forwarding into parliamentary procedure solutions

\footnotetext{
${ }^{23}$ Article $82(2)$ of the Labour Act.
} 
which represent attempts to harmonise certain parts of the national legislation with EU law, the Government receives from the Ministry of European Integration a statement on the harmonisation of the final proposal of the law with the acquis. This implies that the respective proposals have been analysed to a varying extent by sufficiently educated persons who are familiar with particular aspects of European law. However, when such a proposal accompanied by the statement on harmonisation reaches the Parliament and enters the parliamentary procedure, it is subject to numerous discussions, modifications and amendments offered by Members of Parliament, who often do not understand the sense of harmonisation, followed by its adoption in a form which significantly differs from the original proposal. Therefore, such a procedure allows for a solution to be adopted in a much worse form than it was even in the original, i.e. initial phase. The second problem, and a more complex one, refers to a society which is too traditional, conservative and undoubtedly prone not only to gender segregation at all levels, but also to the noticeable stereotypical image of the role of woman and man in family and business life, which can be heard in numerous forms in discussions, even by some male former members of Parliament. The consequences are reflected in the following three problems: first, significant under-representation of women at almost all levels of social life; second, aggravated possibilities of fighting the present prejudice and stereotypes due to deficient legislative solutions and rather low interpretation capabilities of a large proportion of judges, as well as their weak educational background not only in the field of European law, but also in the majority of international sources ratified in the Republic of Croatia, which protect basic individual and collective human rights and freedoms; third, the practice which significantly deviates from the National policy on the promotion of gender equality which very often treats women de facto differently, depending on political trends, and thereby disables their more uniform representation. How can the abovementioned problems be solved? By the created and organised bottom-up principle of working hard for gender equality through labour unions, collective bargaining, NGO activities as well as activities of local and regional bodies. By further efforts concerning remedies in the top-down system, which have to start necessarily by the correction of the Constitution itself, i.e. by its linguistic modification aiming at correcting the absence of sexually neutral language in particular articles tackling such problems. By further harmonisation of the Croatian labour law in the field of gender equality, by a strongly manifested battle against gender segregation as an unquestionable form of indirect discrimination and by taking actions and establishing criteria by which the respective goal can be reached (quota system ${ }^{24}$, positive actions!). By the coordination of the national social security system that would enable us to reach real and full effects of gender equality as well as the affirmation of the principle of equal pay for equal work and work of equal value. And finally, by systematic support given to the promotion of gender equality as well as equality of every human being and every individual, both at all levels of social life and throughout the whole education system. In this respect, we cannot leave out the need for further education and vocational training of judges for the purpose of their being able, in the field of labour law, to provide adequate protection against gender discrimination, and to affirm the principles adopted in Croatian and international sources.

\footnotetext{
24 "Positive discrimination is of course legal and acceptable, but quotas seem only to be virtuous on a case by case basis, not as an automatism.' 'Cf. Blanpain, R. op. cit., p. 305.
} 